\title{
PROFILING OF ANTI-FUNGAL ACTIVITY OF Trichoderma virens 159C INVOLVED IN BIOCONTROL ASSAY OF Ganoderma boninense
}

\section{LEE PEI LEE ANGEL*; SHAMALA SUNDRAM*; BONNIE TAY YEN PING*; MOHD TERMIZI YUSOF** and INTAN SAFINAR ISMAIL ${ }^{\ddagger}$}

\begin{abstract}
Trichoderma has long been recognised as a potential biological control agent (BCA) against pathogenic fungi due to antagonistic characteristics and it has successfully controlled Ganoderma boninense at the nursery stage in previous study. This study attempts to identify the mechanisms involved in the suppression of $\mathrm{G}$. boninense and the anti-fungal compounds released by endophytic Trichoderma virens 159c. Therefore, culture filtrates of endophytic T. virens $159 \mathrm{c}$ was extracted using hexane, ethyl acetate (EtOAc) and butanol $(\mathrm{BuOH})$ and anti-fungal activity was tested. The EtOAc extract showed highest anti-fungal activity with percentage inhibition of radial growth (PIRG) of $78.39 \% \pm 5.40$. The scanning electron microscope (SEM) showed severe deformation of G. boninense PER 71 mycelia observed at the inhibition region caused by EtOAc extract. Further fractionated with column chromatography and antifungal assay revealed that fractions 2 and 4 had highest anti-fungal activity. Analysis carried out using gas chromatography-mass spectrometry detector of the active fraction allowed the identification of acetamide, alcohol, lactones and free fatty acids. Phenylethyl alcohol (PEA) was discovered as a unique compound because the presence was only in the highly inhibitory fraction of T. virens. In addition, dl-mevalonic acid lactone in fraction 4 of $\mathrm{T}$. virens $159 \mathrm{c}$ was first reported in $\mathrm{T}$. virens.
\end{abstract}

\section{Keywords: endophytes, anti-fungal, Trichoderma virens, biological control agent, Ganoderma boninense.}

Date received: 13 May 2017; Sent for revision: 6 June 2017; Received in final form: 11 August 2017; Accepted: 7 September 2017.

\section{INTRODUCTION}

Biological control agent (BCA) is defined as the use of a single or mixed culture of organisms to control phytopathogens and to allow the restoration of some

\footnotetext{
Malaysian Palm Oil Board,

6 Persiaran Institusi, Bandar Baru Bangi,

43000 Kajang, Selangor, Malaysia.

E-mail: shamala@mpob.gov.my

** Department of Microbiology,

Faculty of Biotechnology and Biomolecular Sciences,

Universiti Putra Malaysia, 43400 UPM Serdang,

Selangor, Malaysia.

‡ Department of Chemistry, Faculty of Science;

Universiti Putra Malaysia, 43400 UPM Serdang,

Selangor, Malaysia.
}

regulating factors that limits the competitive ability of pathogens (Chet and Inbar, 1994). Antibiosis is an important attribute of BCA which produces both secondary metabolites and enzymes that are responsible for the suppression of various pathogens ranging from bacteria to fungi (Whipps, 1997). There are 1500 compounds of fungal metabolites which have been identified from various fungi, and more than half of these are found to be anti-bacterial, antitumour or anti-fungal metabolites (Keller et al., 2005; Derntl et al., 2017). Anti-fungal agents are known to have their own mechanisms of action in disrupting the metabolism of pathogens (Ghannoum and Rice, 1999; Johann et al., 2012). Due to these properties, anti-fungal compounds are of major interest to 
be explored further. Antibiosis is a widespread strategy used by Trichoderma for defence against plant pathogens (Hjeljord and Tronsmo, 1998). The role of these secondary metabolites is revealed as being important compounds that lead to the success of antibiosis (Vinale et al., 2006; 2008; Reino et al., 2007; El-Hasan et al., 2009). Recently, fungal endophytes are recognised as prolific producers of structurally unique and biologically active natural secondary metabolites with excellent mechanisms of antibiosis (Kusari et al., 2012; Zhang et al., 2013). Iron acquisition is an important mechanisms for BCA as iron is an essential element in metabolic and informational cellular pathways for most organisms (Howard, 1999; Symeonidis and Marangos, 2012). It is usually aided by the synthesising low molecular weight iron chelators by most microorganisms under conditions of iron starvation known as siderophore (Miethke and Marahiel, 2007) and can be detected with chrome azurol S (CAS) agar (Schwyn and Neilands, 1987). Therefore, the battle between the pathogen and the BCA for iron acquisition has been an interesting interaction as both microorganisms require the element for survival. Sundram (2013) isolated endophytic Trichoderma from oil palm roots and investigated its anti-fungal activity against Ganoderma boninense. In addition, nursery and field trials conducted by Sundram et al. (2016) showed significant Ganoderma disease suppression after application of these endophytic $T$. virens. G. boninense is a pathogen that caused basal stem rot disease (BSR) to oil palm. BSR disease is currently a major threat to the oil palm industry in Malaysia that leads to serious economic losses (Fee, 2011). As a matter of fact, there are several species of Ganoderma involved in BSR infection but $G$. boninense was reported to be the most aggressive compared to the others (Idris, 1999). Previously, Angel et al. (2016) studied the activity of the potential endophytic T. virens $7 \mathrm{~b}$ against $G$. boninense and a notable discovery is the secretion of phenylethyl alcohol (PEA) by T. virens, which has not been reported previously. Hence, the present investigation aims to evaluate the chemical and physical mechanism of another potential endophytic strain isolated from oil palm roots, T. virens 159c against G. boninense and identify the compounds responsible in suppressing the pathogen's growth.

\section{METHODOLOGY}

\section{Source of Endophytic Trichoderma}

The endophytic isolate, $T$. virens $159 c$, was supplied by Ganoderma and Diseases Research for Oil Palm (GanoDROP) Unit, Malaysian Palm Oil Board (MPOB), Malaysia and selected based on two screening methods; dual culture and poison agar technique (Sundram, 2013). The isolate was maintained at $28^{\circ} \mathrm{C}$ in potato dextrose agar (PDA) (Difco, France) at dark. Trichoderma strain was characterised and identified using ITS primers: TW81 (5'-GTTTCCGTAGGTGAACCTGC-3') and AB28 (5'-ATATGCTTAAGTTCAGCGGGT-3') (Howlett et al., 1992). ITS regions that have been used to distinguish the taxa between fungal isolates, hence ITS-based markers will be carried out for identification process (Badotti et al., 2017). G. boninense PER 71, pathogen used for this study was isolated by Idris (1999) from Teluk Intan, Perak, Malaysia and was maintained with PDA at $28^{\circ} \mathrm{C}$ in the dark.

\section{Siderophore Detection of Trichoderma virens 159c}

Detection of the production of siderophore by T. virens 159c was done as described by Milagres et al. (1999). Petri dishes containing $25 \mathrm{ml}$ of $2 \%$ malt extract agar (MEA) were prepared. The medium was cut into half after it solidified and was replaced by CAS-blue agar. The halves containing MEA was inoculated with T. virens 159c. The inoculum was placed as far as possible from the borderline between the two media. The plates were incubated at $28^{\circ} \mathrm{C}$ for three weeks. The rate of colour changes on CAS-blue agar by T. virens 159c were monitored and recorded. All experiments were conducted in five replicates.

\section{Culture Filtrate Cultivation and Solvent Extraction}

The methodology was adapted from Angel et al. (2016). Dried hexane, ethyl acetate (EtOAc), butanol (BuOH) extracts of T. virens $159 \mathrm{c}$ and crude T. virens $159 \mathrm{c}$ extracts were obtained from the extraction and the dried extract was maintained at $-30^{\circ} \mathrm{C}$.

\section{Anti-fungal Properties of T. virens 159c Extracts towards Ganoderma boninense}

The effects of extracts with increasing polarity were determined with assay described by Angel et al. (2016) previously. Benlate ${ }^{\circledR}$, a chemical fungicide act as a positive control. The anti-fungal assay was performed using five replicates. The plates were incubated at $28^{\circ} \mathrm{C}$, and G. boninense PER 71 growth was monitored after 1, 3, 5, 7 and 8 days. The PIRG of G. boninense PER 71 on Day 7 was calculated.

\section{Observation of Mycelia Using a Scanning Electron Microscope (SEM)}

Mycelial discs with healthy G. boninense PER 71 that were subjected to different treatments using T. virens 159c extracts (hexane, EtOAc, and $\mathrm{BuOH}$ extracts) and mycelia disc subjected to positive control (Benlate ${ }^{\circledR}$ ) were prepared. Preparation of 
Ganoderma mycelia for SEM was based on Alves et al. (2013) and Angel et al. (2016). The morphology of each $G$. boninense mycelia were observed under SEM.

\section{Isolation of Fractions from Trichoderma virens 159c EtOAc Extract by Column Chromatography}

The in vitro bioassay revealed that the EtOAc fraction of $T$. virens $159 \mathrm{c}$ had the most significant anti-fungal activity against G. boninense PER 71 . Therefore, this fraction was selected for further purification. The EtOAc extract was subjected to column chromatography over silica gel (Merck, 230-400 mesh, Germany) for the separation of different constituents using a mixture of solvents: DCM (Qrec, Thailand), EtOAc (Qrec, Thailand) and ethanol (EtOH) (Qrec, Thailand). The column, packed with silica gel $15 \mathrm{~cm} \times 3.5 \mathrm{~cm}$, was eluted with DCM, DCM-EtOAc, EtOAc-EtOH in increasing order of polarities to obtain a total of 13 fractions by collecting $200 \mathrm{ml}$ of each fraction. The isolated fraction was evaporated to dryness with a rotary evaporator at $60^{\circ} \mathrm{C}$. The dried extract was measured and kept at $-30^{\circ} \mathrm{C}$.

\section{Anti-fungal Activity of Fractionated Extract from Trichoderma virens}

The dried extract weight was measured and it was dissolved in dimethyl sulphoxide (DMSO) at $10 \mathrm{mg} \mathrm{ml}^{-1}$. Thirteen fractions from the column chromatography were tested for anti-fungal activity. The anti-fungal activities of each fraction against G. boninense PER 71 were determined using a modified well diffusion assay (Angel et al., 2016). The anti-fungal assay was performed with five replicates. The plates were incubated at $28^{\circ} \mathrm{C}$, and G. boninense PER 71 growth was monitored for four days. The inhibition zone distance was calculated by measuring the distance from both sides of mycelium end towards the well.

Identifying the Bioactive Compounds in the Active Fraction Using a Gas ChromatographyMass Spectrometry Detector (GC-MSD)

The active fractions, fraction $2(170.6 \mathrm{mg})$ and fraction $4(51.8 \mathrm{mg})$ obtained from column chromatography were dissolved in a mixture of EtOAc and methanol $(1: 1 ; \mathrm{v}: \mathrm{v})$ to $10 \mathrm{mg} \mathrm{ml}^{-1}$. The samples were injected to GC-MSD (Agilent Technologies 7890A, USA) equipped with the nonpolar capillary column HP5 (30 m length $x 0.25$ mm i.d., $0.25 \mu \mathrm{m}$ film thickness) and helium (99\% purity) as the carrier gas at a $2 \mathrm{ml} \mathrm{min}^{-1}$ flow rate. The method was adapted from Angel et al. (2016). The compounds were identified based on matching between the mass spectra (MS) of unknown and reference compounds in the National Institute of Standards and Technology (NIST) library.

\section{Statistical Analysis}

The statistical analyses were performed using the Statistical Package of Social Science (SPSS). Tukey's test at $\mathrm{P}<0.05$ was applied to determine whether differences between treatments were significant. All the data was arcsine transformed before added to the statistical analysis.

\section{RESULTS}

\section{Identifying Endophytic Trichoderma}

Based on the polymerase chain reaction (PCR) analyses, the ITS region of the T. virens $159 \mathrm{c}$ was amplified at $700-750 \mathrm{bp}$. The sequence analysis for the T. virens 159c isolate exhibited $99 \%$ identity to the Trichoderma virens strain isolated from soil matched through NCBI blasting. The sequence data for T. virens $159 \mathrm{c}$ was submitted to the National Institute of Standards and Technology (NCBI) and given accession numbers KT363921 (T. virens 159c).

\section{Efficiency of Siderophore Production by} Trichoderma virens 159c

The siderophore production of the antagonistic fungal strains $T$. virens $159 \mathrm{c}$ was observed based on the colour changes in the CAS-blue agar. Figure $1 a$ shows that the control CAS-blue agar plate remained blue even after 21 days of incubation. $T$. virens 159 c only required three days to reach the border of the plate despite insufficient iron content in $2 \%$ MEA. There was rapid change of the CASblue agar since most of the agar turned yellow in 14 days (Figure 1b) and completely yellow in less than 21 days (Figure $1 c$ ).

Efficacy of Fractionated Culture Filtrates of T. virens $159 \mathrm{c}$ in the Inhibition of Ganoderma boninense

Table 1 shows the PIRG of G. boninense PER 71 when tested with different extracts of $T$. virens $159 \mathrm{c}$. The results showed that EtOAc extract $(78.39 \%$ \pm 5.40 ) gave the best suppression of $G$. boninense PER 71 as compared to the other two extracts. In addition, the EtOAc extract's performance was comparable with Benlate ${ }^{\circledR}$ which gave a percentage inhibition of radial growth (PIRG) of $79.88 \% \pm 2.80$ with no significance difference. This also provides information that the anti-fungal activity is mostly contributed by a mixture of polar and non-polar compounds. Figure 2 illustrates the suppression on G. boninense PER 71 by the different extracts and EtOAc extracts (Figure 2d) showed highest inhibition towards G. boninense PER 71. 

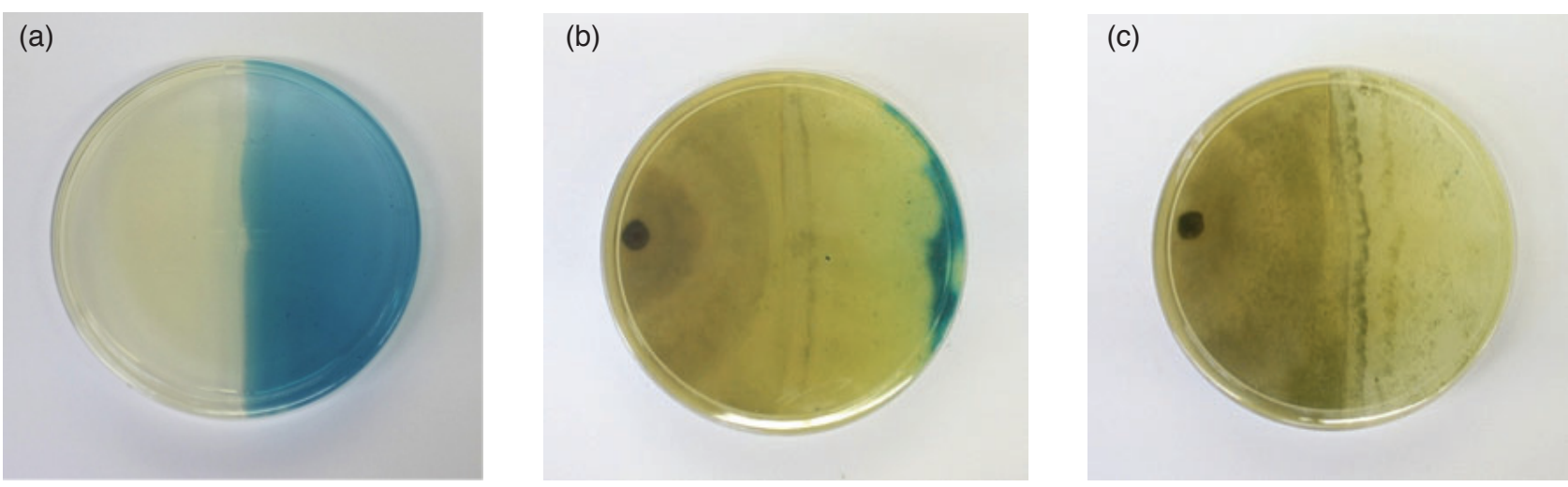

Figure 1. Trichoderma virens 159 c siderophore detection using the chrome azurol S (CAS) plate agar assay; (a) CAS-blue agar without presence of T. virens 159c (control); (b) T. virens 159c incubated for 14 days; (c) T. virens 159c incubated for 21 days.

\section{Observation of G. boninense Mycelia Using SEM}

The mycelia subjected to blank DMSO as negative control was presented in a normal and intact tubular shape with smooth cell wall (Figure $3 a$ ). However, prominent changes of the G. boninense hyphae were found after subjected to crude culture filtrate extract. There were clumping and irregular

\section{TABLE 1. INHIBITION OF Ganoderma boninense BY CHEMICAL AND CULTURE FILTRATES OF} Trichoderma virens $159 \mathrm{c}^{*}$

\begin{tabular}{lc}
\hline Type of extract & $\begin{array}{c}\text { Percentage inhibition of } \\
\text { radial growth, } \%\end{array}$ \\
\hline Crude & $44.31 \pm 7.84 \mathrm{a}$ \\
Hexane & $21.85 \pm 3.40 \mathrm{~b}$ \\
Ethyl acetate & $78.39 \pm 5.40 \mathrm{~b}$ \\
Butanol & $2.56 \pm 4.49 \mathrm{c}$ \\
Benlate $^{\circledR}$ (Positive control) & $79.88 \pm 2.80 \mathrm{~d}$ \\
\hline
\end{tabular}

Note: *Percentage of inhibition growth was calculated using blank dimethyl sulphoxide (DMSO) as a negative control. Each value is the mean percentage of three experiments \pm standard deviation. Means within the same column followed by the superscript of same letters are not significantly different at $\mathrm{P}<0.05$ with Tukey's test. swelling of the mycelia as seen in Figure $3 b$ in which causing the morphological defect on the mycelia of $G$. boninense. The detached and broken mycelia characteristics caused by EtOAc extract of T. virens $159 \mathrm{c}$ (Figure 3c) caused the mycelia network in an inorganised manner. However, a different hyphal morphology was observed when subjected to Benlate $^{\circledR}$ (Figure $3 d$ ) when compared with the EtOAc extract where the deformation of hyphae was mainly clumping.

\section{Screening of the Anti-fungal Activity for Each Column Eluted Fraction against $G$. boninense}

EtOAc extraction yielded higher amount of extracts compared to hexane extraction. The column separation resulted in 13 fractions which were subjected for screening against the pathogen. The anti-fungal assay showed fractions 2, 3, 4, 5, 6, 7, and 8 were highly inhibitory against $G$. boninense PER 71 (Figure 4) with inhibition at $23.4 \mathrm{~mm}, 22.7$ $\mathrm{mm}, 24.2 \mathrm{~mm}, 21.5 \mathrm{~mm}, 22.4 \mathrm{~mm}, 23.7 \mathrm{~mm}$, and 22.3 $\mathrm{mm}$, respectively after four days of incubation. The inhibition by crude EtOAc extract from T. virens 159 c $(21.9 \mathrm{~mm})$ was equally effective as the fractionated

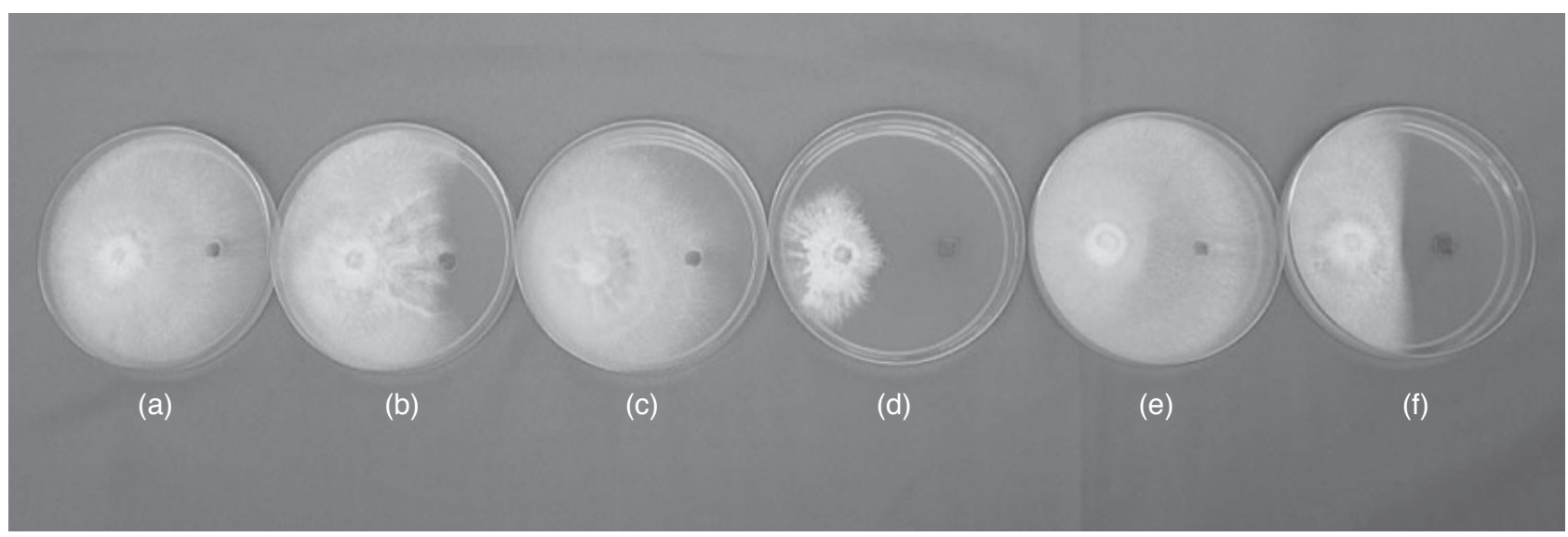

Figure 2. Effect of crude and fractionated Trichoderma virens $159 \mathrm{c}$ extract against Ganoderma boninense; (a) negative control; (b) crude extract; (c) hexane extract; (d) ethyl acetate $(E t O A c)$ extract; (e) butanol (BuOH) extract; $(f)$ Benlate ${ }^{\circ}$. 

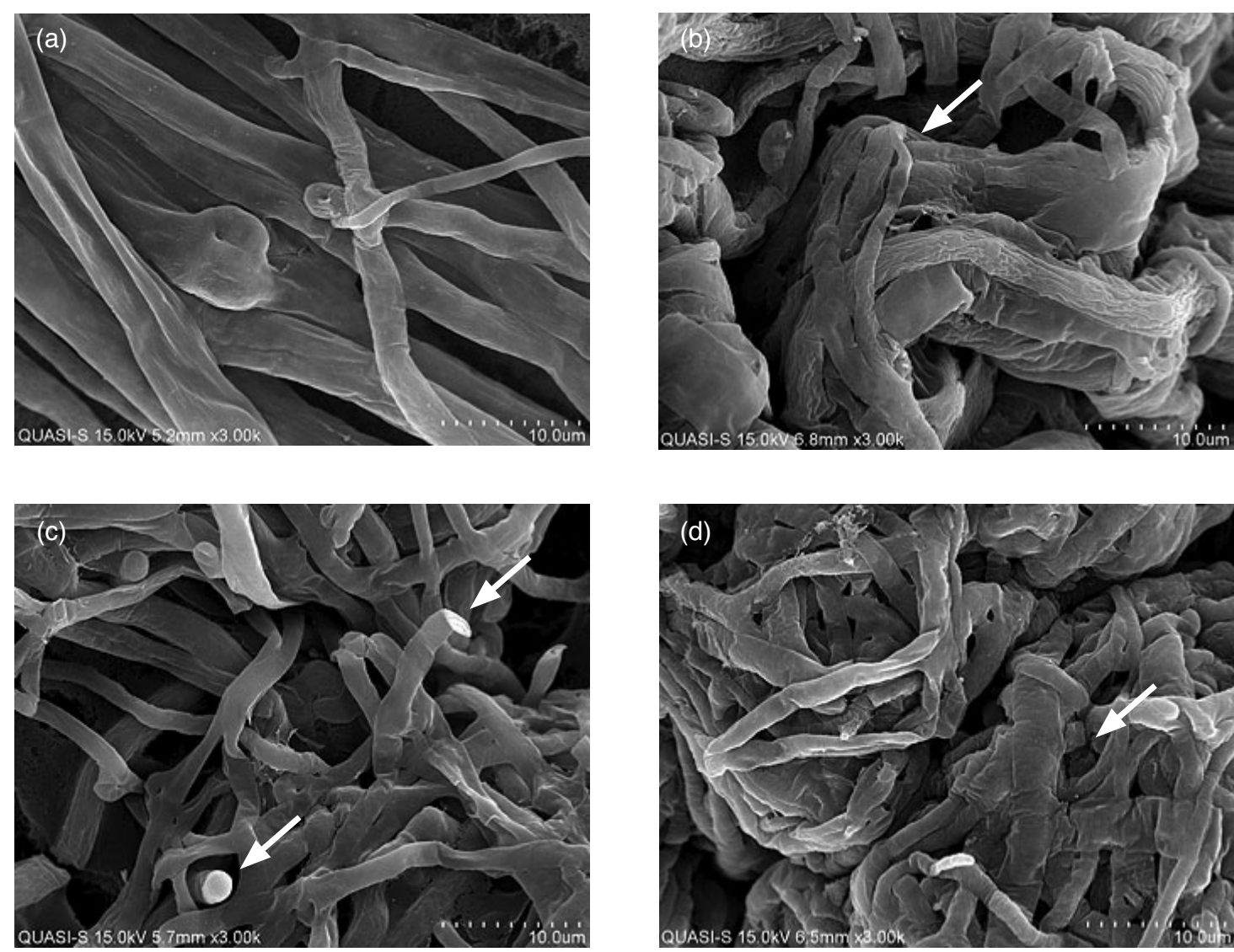

Figure 3. The effects of the extract of Trichoderma virens $159 \mathrm{c}$ on mycelium of Ganoderma boninense PER 71 viewed under scanning electron microscope (SEM) (10 $\mu \mathrm{m})$; (a) negative control; (b) crude extract; (c) ethyl acetate (EtOAc) extract; (d) Benlate ${ }^{\circledR}$. Arrow showing abnormalities on the Ganoderma hyphae.

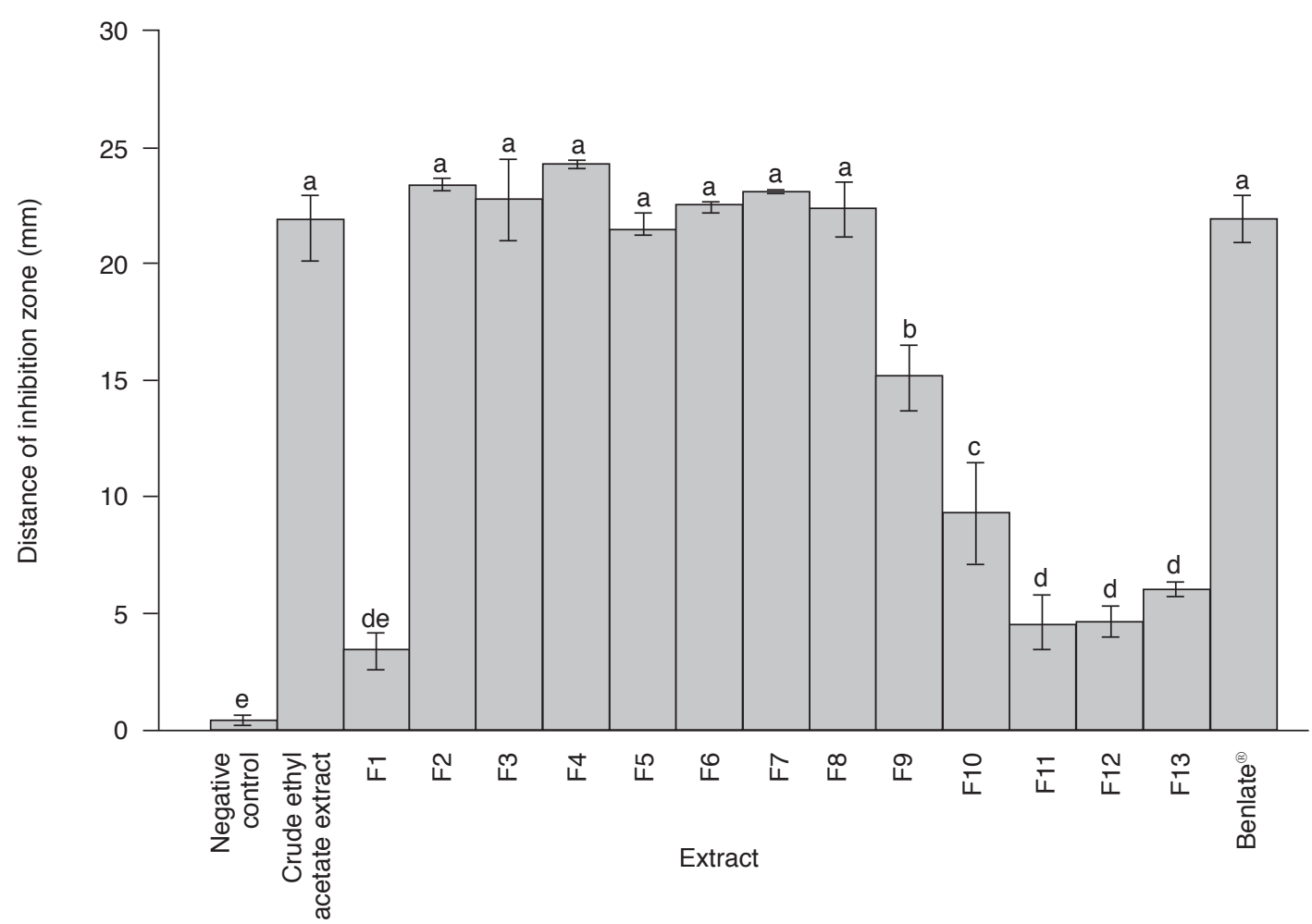

Figure 4. Distances of inhibition zones $(\mathrm{mm})$ of fractions $(\mathrm{F})$ of Trichoderma virens $159 \mathrm{c}$ ethyl acetate (EtOAc) extract. Blank dimethyl sulphoxide (DMSO) as negative control. Each value is the mean percentage of three experiments \pm standard deviation. Means within the same column with the same superscript letters are not significantly different at $P<0.05$ with Tukey's test. 
extracts with no significant difference with all seven active extracts. The G. boninense PER 71 was found healthy in the negative control plate after four days of incubation. The efficiency of the active extracts from T. virens 159c was further confirmed as the activity was not significant with the anti-fungal activity caused by Benlate ${ }^{\circledR}$. However, fractions 2 and 4 showed the highest inhibitions among the other active extracts and might have consisted of anti-fungal compounds that highly suppressed the growth of $G$. boninense PER 71. The two fractions were subjected for further evaluation.

\section{Identification of Semi-polar Compounds Produced by $T$. virens 159c with GC-MSD}

The results presented in Tables 2 and 3 were profiles of compounds in active fractions 2 and fraction 4 of $T$. virens 159 c that were possibly responsible for the inhibition of $G$. boninense PER 71. The chromatograms are shown in Figure 5. A total of 14 compounds in fraction 2 (Table 2), nine compounds in fraction 4 (Table 3) were identified using the NIST library with a probability matching greater than $50 \%$.

\section{DISCUSSION}

The ability to compete for nutrients with pathogenic fungi is a key mechanism that allows the antagonistic fungi to become a successful biocontrol agent. In this study, the ability of T. virens $159 \mathrm{c}$ and $G$. boninense in the release of siderophores (a chelator ions) for the uptake of iron was studied by using CAS assay, which is generally used method to detect the siderophore by microorganisms (Schwyn and Neilands 1987). The observation showed that T. virens 159c being superior producer of siderophore when compared to the endophytic T. virens $7 \mathrm{~b}$ reported by Angel et al. (2016). Differences in the discolouration of the CASblue agar showed that different types of siderophore

TABLE 2. METABOLITES IDENTIFIED FROM FRACTION 2 OF Trichoderma virens 159c ETHYL ACETATE (EtOAc) EXTRACT USING A GAS CHROMATOGRAPHY-MASS SPECTROMETRY DETECTOR (GC-MSD)

\begin{tabular}{|c|c|c|c|c|}
\hline No. & Metabolites & Retention time (min) & $\begin{array}{l}\text { Matching of spectra } \\
(\%)\end{array}$ & $\begin{array}{c}\text { Percentage composition* } \\
(\%)\end{array}$ \\
\hline 1 & Cyclopentanol, 1-methyl & 4.306 & 80.3 & 7.7 \\
\hline 2 & Cyclopentanol, 3-methyl & 5.526 & 56.3 & 1.7 \\
\hline 3 & Unknown & 7.194 & - & 10.9 \\
\hline 4 & Unknown & 7.398 & - & 3.8 \\
\hline 5 & Unknown & 7.906 & - & 8.5 \\
\hline 6 & 3,4-dimethylpent-2-en-1-ol & 8.516 & 87.7 & 3.1 \\
\hline 7 & Unknown & 9.072 & - & 11.1 \\
\hline 8 & Unknown & 9.291 & - & 46.8 \\
\hline 9 & Unknown & 10.147 & - & 2.3 \\
\hline 10 & Unknown & 11.607 & - & 1.4 \\
\hline 11 & Phenylethyl alcohol & 13.752 & 87.3 & 1.9 \\
\hline 12 & Acetamide, N-(2-phenylethyl) & 24.545 & 82.3 & 0.2 \\
\hline 13 & Dodecanoic acid & 25.738 & 79.0 & 0.1 \\
\hline 14 & $\begin{array}{l}\text { Pyrrolo (1,2a) pyrazine, } 1 \text {,4-dione } \\
\text { hexahydro-3-(2 methylpropyl })\end{array}$ & 33.520 & 85.9 & 0.5 \\
\hline
\end{tabular}

Note: *Percentage composition based on peak height.

TABLE 3. METABOLITES IDENTIFIED FROM FRACTION 4 OF Trichoderma virens 159c ETHYL ACETATE (EtOAc) EXTRACT USING A GAS CHROMATOGRAPHY-MASS SPECTROMETRY DETECTOR (GC-MSD)

\begin{tabular}{lcccc}
\hline No. & Metabolites & Retention time (min) & $\begin{array}{c}\text { Matching of spectra } \\
(\%)\end{array}$ & $\begin{array}{c}\text { Percentage composition* } \\
(\%)\end{array}$ \\
\hline 1 & Cyclopentanol, 1-methyl & 4.317 & 50.0 & 3.8 \\
2 & $1,3-$ Octanediol & 6.815 & 51.4 & 0.9 \\
3 & dl-mevalonic acid lactone & 18.036 & 93.9 & - \\
4 & Unknown & 18.630 & - & 0.9 \\
5 & Unknown & 20.325 & 74.0 & 3.1 \\
6 & Benzeneethanol, 4-hydroxy & 22.545 & - & 6.6 \\
8 & Unknown & 23.727 & - & 1.5 \\
9 & Unknown & 25.749 & 81.4 & 67.1 \\
\hline
\end{tabular}

Note: * Percentage composition based on peak height. 

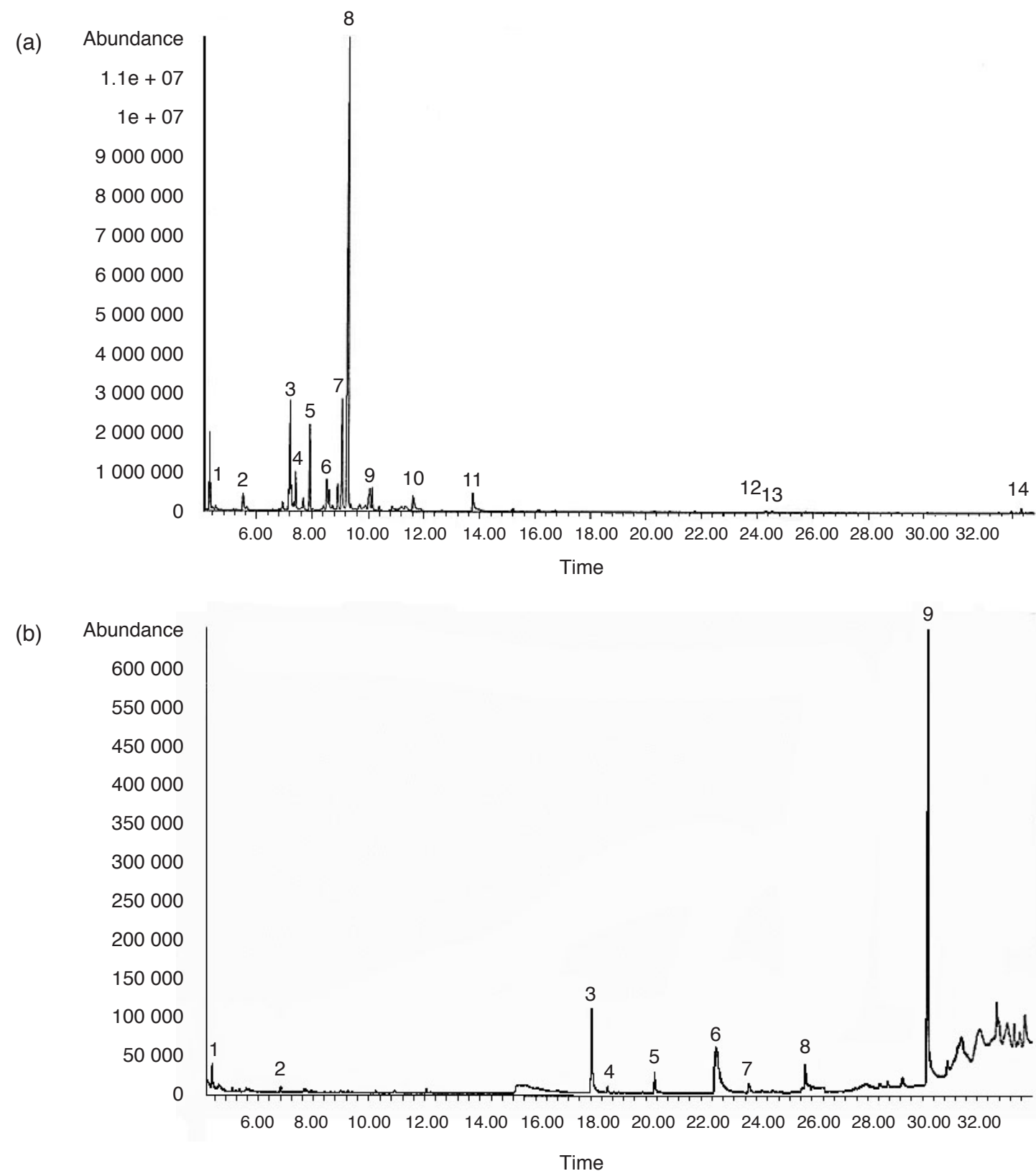

Figure 5. Gas chromatography-mass spectrometry detector (GC-MSD) profiles of (a) fraction 2 and (b) fraction 4 ethyl acetate (EtOAc) extract from Trichoderma virens 159c.

were being released (Miethke and Marahiel, 2007). It was observed that $T$. virens $159 \mathrm{c}$ secreted the hydroxamate type of siderophore similar to T. virens $7 \mathrm{~b}$ reported previously. Trichoderma were reported as hydroxamate producers and hydroxamate siderophores possessed higher stability compared to other types of siderophores which may be a factor for their ecological predominance (Helm and Winkelmann, 1994; Wilhite et al., 2001). On the contrary, G. boninense PER 71 produced siderophores at a much slower rate which showed that the superiority of the endophytic Trichoderma in iron acquisition (Angel et al., 2016). This phenomenon left G. boninense PER 71 in the iron starvation mode. The rate of siderophore production for a potential BCA is very important in the competition for nutrients with the pathogens, as it creates iron starvation in the environment by acquiring the available nutrient for survival (Loper and Buyer, 1991). This study revealed that T. virens $159 \mathrm{c}$ is able to utilise a high affinity iron transport system and efficiently produce siderophores to compete under iron deficient conditions.

In the present work, the secondary metabolites released from $T$. virens $159 \mathrm{c}$ were characterised to identify the potential compounds that are responsible in the inhibition of G. boninense PER 71. Usage of solvents with different polarities allowed discrimination between non-polar and polar fraction activities (Mahlke et al., 2009). The EtOAc extract 
of $T$. virens $159 \mathrm{c}$ effectively inhibited the activity of $G$. boninense PER 71 which might be due to the enrichment of anti-fungal compounds in the EtOAc extract without any interference of the other nonactive compound from the other fractions (Krishna Reddy et al., 2009). These findings are in agreement with various studies that was carried out in evaluating the anti-fungal properties of Trichoderma using EtOAc extraction (El-Hasan et al., 2009; Vinale et al., 2009), showing greater biological activity in semi-polar rather than other polarities. However, different Trichoderma strains produced different types of secondary metabolites in order to defend against the pathogenic fungi (Jeleń et al., 2013). Although both endophytic Trichoderma ( $T$. virens $7 \mathrm{~b}$ and $159 \mathrm{c}$ ) were identified as $T$. virens, distinct characteristics were observed. The growth pattern for both Trichoderma were different on PDA plate and the colour changed of potato dextrose broth (PDB) after incubation of $T$. virens $159 \mathrm{c}$ for seven days was lighter compared to T. virens $7 \mathrm{~b}$. Different results were observed as hexane extract of $T$. virens $7 \mathrm{~b}$ possessed higher inhibition effect towards $G$. boninense PER 71 instead of ethyl acetate extract (Angel et al., 2016). This explains the production of metabolites is strain dependent, whereby different strain of same species can produce different types of metabolites with different effects on target pathogens (Bailey et al., 2010). Therefore, both strains showed different anti-fungal activities and produces different metabolites compounds.

Deformation of hyphae caused by EtOAc extract observed in the study confirmed the presence of anti-fungal agents in the active extract that was responsible for the disturbance of $G$. boninense PER71 growth (Mares et al., 2004; Kim et al., 2012). This was achieved due to the biosynthesis of a wide array of secondary metabolites (Reino et al., 2007). Although there was a slight difference in the form of damage caused by Benlate ${ }^{\circledR}$, EtOAc extract from T. virens $159 \mathrm{c}$ still possessed unique mechanism which also efficiently caused lethal damage to the hyphae which eventually inhibited the growth of G. boninense. As mentioned earlier, the mechanism of action for each anti-fungal compound was mainly based on their site of action (Ghannoum and Rice, 1999). The EtOAc extract of T. virens 159c might consist of anti-fungal compounds that caused the detachment of the hyphae which explains the difference in the modes of action of the EtOAc extract and Benlate ${ }^{\circledR}$. Benlate, which is also known as benomyl is a wide spectrum fungicide that was designed to interfere with fungal cell division and could lead to disruption of microtubules (Hauptmann et al., 1985). Hexane extract from $T$. virens $7 \mathrm{~b}$ reported by Angel et al. (2016) also showed different mode of damages to the hyphae of $G$. boninense. Therefore, it is important to characterise the Trichoderma strain to understand the role of antibiosis in suppressing the growth of G. boninense.

Based on the results, fractions 2 and 4 expressed highest anti-fungal activities towards $G$. boninense PER 71. These fractions constituted of acetamide, alcohol, lactones and free fatty acids that might be contributed to the suppression of the pathogen. Acetamide, N-(2-phenylethyl), was reported in the extract of Inocybe geophylla to have anti-fungal activity against the pathogenic fungi, Fusarium oxysoprum (Reinoso et al., 2013). Two fatty acids were identified; dodecanoic acid (fraction 2) and tetradecanoic acid (fraction 4). The higher percentage composition of tetradecanoic acid in fraction 4 of $T$. virens 159 c might play a key role in the anti-fungal activities to give highest inhibition towards G. boninense PER 71. Fatty acids had been reported previously to have anti-fungal and anti-bacterial activities (Hilgren and Salverda 2000; Aneja et al., 2005; Pohl et al., 2011). They can insert themselves into lipid bi-layer of fungal membranes, physically disturb the membrane which caused the increased in fluidity that leads to conformational changes of membrane protein (Pohl et al., 2011). Other compounds identified from these active fractions was pyrrolo $(1,2 a)$ pyrazine, 1,4-dione hexahydro-3-(2 methylpropyl), a pyrrolo ring derivative (methylpropyl). Similar pyrrolo compounds with methylpropyl derivatives from Streptomyces sp. were implicated in anti-fungal activities by Jog et al. (2014), where studies showed that Streptomyces strain that inhibits the growth of fungal pathogens produces this low molecular mass compound. However, compare to the GC-MSD profile of the Streptomyces strain in Jog et al. (2014), the level of detection for pyrrolo $(1,2 \mathrm{a})$ pyrazine, 1,4-dione hexahydro-3-(2 methylpropyl) is higher compared to T. virens $159 \mathrm{c}$. Another compound known as $d l$-mevalonic acid lactone was identified in fraction 4 . The $d l$-mevalonic acid lactone was reported by Scopel et al. (2014) and significant inhibition to Staphylococcus epidermidis and interfere with its biofilm formation. However, $d l$-mevalonic acid lactone was never reported in $T$. virens and it was first discovered in this strain (T. virens $159 \mathrm{c}$ ). This compound might contribute to the inhibition activity towards G. boninense PER 71 as it was detected at the active fraction of T. virens 159c. PEA was identified in fraction 2 of T. virens $159 c$, which was also identified in active band of $T$. virens $7 \mathrm{~b}$ by Angel et al. (2016) and it was the first report of PEA to be secreted by T. virens. Band 5 of the hexane extract of $T$. virens $7 \mathrm{~b}$ (Angel et al., 2016) and fraction 2 of the EtOAc extract of T. virens 159c efficiently suppressed the growth of $G$. boninense PER 71 probably due to the presence of PEA in both fractions. PEA showed strong inhibition against mycelial growth of fungal pathogens (Rouissi et al., 2013) and the anti-bacterial activity of PEA was also reported previously (Corre et al., 1990). However, there were three compounds 
in common namely PEA, 3, 4-dimethylpent-2-en-1$\mathrm{ol}$ and dodecanoic acid were compounds identified in the highly inhibitory fractions of extracts of both endophytic Trichoderma, namely the hexane extract of $T$. virens $7 \mathrm{~b}$ (band 5) and the EtOAc extract of $T$. virens $159 \mathrm{c}$ (fraction 2). However, there was no report on the anti-fungal activity of 3, 4-dimethylpent-2-en-1-ol and its commercial product was not readily available for evaluation. As for dodecanoic acid, it was also found in the other fractions of $T$. virens extract that were not highly active. Hence, PEA was highlighted as unique discovery of $T$. virens because this compound was found only in highly inhibitory fractions from both endophytic $T$. virens $7 \mathrm{~b}$ and $159 \mathrm{c}$ and was first reported to be produced by $T$. virens. The anti-fungal activity was proven with the commercial PEA which produced synthetically against G. boninense (Angel et al., 2016). These compounds identified from the active fractions might be responsible for the inhibition of G. boninense PER 71.

\section{CONCLUSION}

In this article, the study contributes significantly to the understanding of potential mechanisms involved in suppression of $G$. boninense by endophytic $T$. virens 159c. T. virens 159c showed significant and greater Ganoderma disease suppression in nursery and field trials conducted by Sundram et al. (2016) compared to $T$. virens $7 \mathrm{~b}$ after application to the Ganoderma infected oil palm. Same species with two different extraction methods gave rise to different profiling of metabolites. Although both $7 \mathrm{~b}$ and $159 \mathrm{c}$ are from T. virens, they differed in their performance when they were subjected to solvents, which prompted the investigation of using two different separation methods. An interesting discovery was made during the current study whereby PEA was discovered again in highly active fraction of $T$. virens $159 \mathrm{C}$ extract, accordance with the findings of Angel et al. (2016). In addition, $d l$-mevalonic acid lactone found in fraction 4 of $T$. virens 159 c was first discovered in T. virens. The discovery was filed for patent. This study also shows that endophytic $T$. virens 159c have an excellent potential in the inhibition of $G$. boninense and the opportunity to introduce endophytes as biological control which serves as a better solution towards Ganoderma infection to the oil palm.

\section{ACKNOWLEDGEMENT}

The authors thank the Director-General of MPOB for permission to publish this article and for funding of this research project.

\section{REFERENCES}

ALVES, E; LUCAS, G C; POZZA, E A and ALVES, M C (2013). Scanning electron microscopy for fungal sample examination laboratory protocols in fungal biology. Laboratory Protocol in Fungal Biology: Current Methods in Fungal Biology (Gupta, V K; Tuohy, M G; Ayyachamy, M; Turner, K M and O'Donovan, A eds.). Springer, New York. p. 133-150.

ANEJA, M; GIANFAGNA, T J and HEBBAR, P K (2005). Trichoderma harzianum produces nonanoic acid, an inhibitor of spore germination and mycelial growth of two cacao pathogens. Physio and Mol Plant Path Vol. 67: 304-307.

ANGEL, L P L; YUSOF, M T; ISMAIL, I S; TAY, B Y P; MOHAMED AZNI, I N A; KAMARUDIN, N $\mathrm{H}$ and SUNDRAM, S (2016). An in vitro study of the antifungal activity of Trichoderma virens $7 \mathrm{~b}$ and a profile of its non-polar antifungal components released against Ganoderma boninense. J Microbiol Vol. 54: 732-744.

BADOTTI, F; OLIVEIRA, F S; GARCIA, C F; VAZ, A B M; FONSECA, P L C; NAHUM, L A; OLIVEIRA, G and GÓES-NETO, A (2017). Effectiveness of ITS and sub-regions as DNA barcode markers for the identification of Basidiomycota (fungi). BMC Microbiol Vol. 2017: 1-12.

BAILEY, A; CHANDLER, D; GRANT, W P; GREAVES, J; PRINCE, G and TATCHELL, M (2010). Pest management with biopesticides. Biopesticides: Pest Management and Regulation. CABI: UK. p. 71130.

CHET, I and INBAR, J (1994). Biological control of fungal pathogens. Appl Biochem Biotechnol Vol. 48: 37-43.

CORRE, J; LUCCHINI, J J; MERCIER, G M and CREMIEUX, A (1990). Antibacterial activity of phenylethyl alcohol and resulting membrane alterations. Res Microbiol Vol. 141: 483-497.

DERNTL， C; KLUGER， B; BUESCHL， C; SCHUHMACHER, R; MACH, R L and MACHAIGNER, A R (2017). Transcription factor of Xpp1 is a switch between primary and secondary fungal metabolism. Proc. Natl. Acad. Sci. USA. Vol. 114: 560569.

EL-HASAN, A; WALKER, F; SCHÖNE, J and BUCHENAUER, H (2009). Detection of viridiofungin A and other antifungal metabolites excreted by Trichoderma harzianum active against different plant pathogens. Eur J Plant Pathol Vol. 124: 457-470. 
FEE, C G (2011). Management of Ganoderma diseases in oil palm plantations. The Planter Vol. 87: 325-339.

GHANNOUM, MA and RICE, L B (1999). Antifungal agents: mode of action, mechanisms of resistance, and correlation of these mechanisms with bacterial resistance. Clin Microbiol Rev Vol. 12: 501-517.

IDRIS, A S (1999). Basal Stem Rot (BSR) of Oil Palm (Elaeis guineensis Jacq.) in Malaysia: Factors Associated with Variation in Disease Severity. Ph.D. thesis. Wye College, UK.

HAUPTMANN, R M; WIDHOLM, J $\mathrm{M}$ and PAXTON, J D (1985). Benomyl: A broad spectrum fungicide for use in plant cell and protoplast culture. Plant Cell Rep Vol. 4: 129-132.

HELM, D and WINKELMANN, G (1994). Hydroxamates and polycarboxylates as iron transport agents (siderophore) in fungi. Metal Ions in Fungi (Winkelmann, G and Winge, D R eds.). CRC Press, New York. p. 39-98.

HJELJORD, L and TRONSMO, A (1998). Trichoderma and Gliocladium in biological control: An overview. Trichoderma and Glocladium: Enzymes, Biological Control (Harman, G E and Kubicek, C P eds.). CRC Press, New York. p. 61-131.

HILGREN, J D and SALVERDA, J A (2000). Antimicrobial efficacy of a peroxyacetic/octanoic acid mixture in fresh-cut-vegetable process waters. J Food Sci Vol. 65: 1376-1379.

HOWARD, D H (1999). Acquisition, transport, and storage of iron by pathogenic fungi. Clin Microbiol Rev Vol. 12: 394-404.

HOWLETT, B J; BROWNLEE, A G; GUEST, D I; ADCOCK, G J and MCFADDEN, G I (1992). The $5 S$ ribosomal RNA gene is linked to large and small subunit ribosomal RNA genes in the oomycetes, Phytophthora vignae, P. cinnamomi, P. megasperma f.sp. glycinea and Saprolegnia ferax. Curr. Genet Vol. 22: 455-461.

JELEŃ, H; BŁASZCZYK, L; CHEŁKOWSKI, J; ROGOWICZ, K and STRAKOWSKA, J (2013). Formation of 6-n-pentyl-2H-pyran-2-one (6-PAP) and other volatiles by different Trichoderma species. Mycol Prog Vol. 13: 589-600.

JOG, R; PANDYA, M; NARESHKUMAR, G and RAJKUMAR, S (2014). Mechanism of phosphate solubilization and antifungal activity of Streptomyces spp. isolated from wheat roots and rhizosphere and their application in improving plant growth. Microbiology (Reading, Engl) Vol. 160: 778-788.
JOHANN, S; ROSA, L H; ROSA, C A; PEREZ, P; CISALPINO, P S; ZANI, C L and COTA, B B (2012). Antifungal activity of altenusin isolated from the endophytic fungus Alternaria sp. against the pathogenic fungus Paracoccidioides brasiliensis. Rev Iberoam Micol Vol. 29: 205-209.

KELLER, N P; TURNER, G and BENNETT, J W (2005). Fungal secondary metabolism - from biochemistry to genomics. Nature Rev Microbiol Vol. 3: 937-947.

KIM, Y S; KIM, K S; HAN, I; KIM, M H; JUNG, M H and PARK, H K (2012). Quantitative and qualitative analysis of the antifungal activity of allicin alone and in combination with antifungal drugs. PloS One Vol. 7: 1-8.

KRISHNA REDDY, B; BALAJI, M; UMA REDDY, P; SAILAJA, G; VAIDYANATH K and NARASIMHA, G (2009). Antifeedant and antimicrobial activity of Tylophora indica. Afr J Biochem Res Vol. 3: 393-397.

KUSARI, S; HERTWECK, C and SPITELLER, M (2012). Chemical ecology of endophytic fungi: Origins of secondary metabolites. Chem Biol Vol. 19: 792-798.

LOPER, J E and BUYER, J S (1991). Siderophore in microbial interaction on plant surface. Mol Plant Microbe Interact Vol 4: 5-13.

MAHLKE, J D; BOLIGON, A A; MACHADO, M M; SPADER, T B; ALVES, S H; CANTO-DOROW, $\mathrm{T}$ and ATHAYDE, M L (2009). In vitro antimicrobial and antioxidant activities of a crude extract and fractions from Buddleja thyrsoides Lam. leaves. Quim Nova Vol. 32: 277-281.

MARES, D; TOSI, B, POLI, F; ANDREOTTI, E, and ROMAGNOLI, C (2004). Antifungal activity of Tagetes patula extracts on some phytopathogenic fungi: Ultrastructural evidence on Pythium ultimum. Microbiol Res Vol. 159: 295-304.

MIETHKE, $M$ and MARAHIEL, M A (2007). Siderophore-based iron acquisition and pathogen control. Microbiol Mol Vol. 71: 413-451.

MILAGRES, A M F; MACHUCA, A and NAPOLEAO, D (1999). Methods detection of siderophore production from several fungi and bacteria by a modification of chrome azurol S (CAS) agar plate assay. J Microbiol Methods Vol 37: 1-6.

POHL, C H; KOCK, J L F and THIBANE, V S (2011). Antifungal free fatty acids: a review. Science against Microbial Pathogens: communicating Current Research and Technological Advances (Mendez-Vilas, A ed.). Formatex, Spain. p. 61-71. 
REINO, J L, GUERRERO, R F; HERNÁNDEZGALÁN, R and COLLADO, I G (2007). Secondary metabolites from species of the biocontrol agent Trichoderma. Phytochem Rev Vol. 7: 89-123.

REINOSO, R; CAJAS-MADRIAGA, D; MARTINEZ, M; MARTIN, A S; PEREZ C; FAJARDO, V and BECERRA, J (2013). Biological activity of macromycetes isolated from Chilean subantractic ecosystems. J Chil Chem Soc Vol. 58: 2016-2019.

ROUISSI, W; UGOLINI, L; MARTINI, C; LAZZERI, L and MARI, M (2013). Control of postharvest fungal pathogens by antifungal compounds from Penicillium expansum. J Food Prot Vol. 76: 1879-1886.

SCOPEL, M; ABRAHAM, W-R; ANTUNES, A L; HENRIQUES, A T and MACEDO, A J (2014). Mevalonolactone: An inhibitor of Staphylococcus epidermidis adherence and bioflim formation. J Med Chem Vol. 10: 246-251.

SUNDRAM, S (2013). First report: isolation of endophytic Trichoderma from oil palm (Elaeis guineensis Jacq.) And their in vitro antagonistic assessment on Ganoderma boninense. J. Oil Palm Res. Vol. 25: 368-372.

SUNDRAM, S; ANGEL, L P L; TAY, B Y P; ROSLAN, N D; MOHAMED AZNI, I N A and IDRIS, AS (2016). Trichoderma virens, an effective biocontrol agent against Ganoderma boninense. MPOB Information Series No. 587.

SCHWYN, B and NEILANDS, J B (1987). Universal chemical assay for the detection and determination of siderophores. Anal Biochem Vol. 160: 47-56.

SYMEONIDIS, A and MARANGOS, M (2012). Iron and microbial growth. Insight and Control of Infectious
Disease in Global Scenario (Roy, P K ed.). InTech, Croatia. p. 290-330.

VINALE, F; MARRA, R; SCALA, F; GHISALBERTI, E L; LORITO, $\mathrm{M}$ and SIVASITHAMPARAM, K (2006). Major secondary metabolites produced by two commercial Trichoderma strains active against different phytopathogens. Lett Appl Microbiol Vol. 43: 143-148.

VINALE, F; SIVASITHAMPARAM, K; GHISALBERTI, E L, MARRA, R; BARBETTI, M J; LI, H; WOO, S L and LORITO, M (2008). A novel role for Trichoderma secondary metabolites in the interactions with plants. Physiol Mol Plant Pathol Vol. 72: 80-86.

VINALE, F; GHISALBERTI, E L; SIVASITHAMPARAM, K; MARRA, R; RITIENI, A; FERRACANE, R; WOO, S and LORITO, M (2009). Factors affecting the production of Trichoderma harzianum secondary metabolites during the interaction with different plant pathogens. Lett Appl Microbiol Vol. 48: 705-711.

WILHITE, S E; LUMSDEN, R D and STRANEY, D C (2001). Peptide synthetase gene in Trichoderma virens. Appl Environ Microbiol Vol. 67: 5055-5062.

WHIPPS, J M (1997). Interactions between fungi and plant pathogens in soil and the rhizosphere. Multitrophic Interactions in Terrestrial System (Gange, A C and Brown, V K eds.). Blackwell Science Ltd, UK. p. 47-59.

ZHANG, G; ZHANG, Y; QIN, J; QU, X; LIU, J; LI, X and PAN, H (2013). Antifungal metabolites produced by Chaetomium globosum No. 04, an endophytic fungus isolated from Ginkgo biloba. Indian J Microbiol Vol. 53: 175-180. 